\title{
Critical Thinking Module in Promoting Higher Order Thinking Skills among Secondary School Students
}

\author{
Norhezan Che Teh \\ Nor Hashimah Isa \\ \& \\ Ainon Omar \\ Department of English Language and Literature \\ Universiti Pendidikan Sultan Idris \\ Email: shima@fbk.upsi.edu.my,ainon@fbk.upsi.edu.my
}

\begin{abstract}
The purpose of this paper is to demonstrate how the Critical Thinking Module could be used in Literature classes as a teaching tool in assisting students to embark on higher order thinking. This is in line with the Malaysia Education Blueprint 2013 - 2025 that stresses the importance of mastery of higher order thinking skills among students. This case study took place for 19 weeks with 9 subjects from a cluster school. The medium used was a short story written by Che Husna Azhari, a local writer. The subjects sat for 3 tests and the results showed that the subjects employed higher order thinking skills in their answers to the questions posed. Therefore, this research proposes that the Critical Thinking Module be used as a teaching aid to assist the teachers in incorporating higher order thinking skills in their Literature classes.
\end{abstract}

Keywords: Literature, higher-order thinking skills (HOTs), Critical Thinking Module

\section{INTRODUCTION}

Education is not a static entity. It evolves and changes with the needs of the global world to ensure the competitiveness of a country. Taking into consideration Malaysian students' performance in PISA and the apprehensiveness of employers of the disparity that exists between the skills that Malaysian graduates need and the skill that they acquire in their learning institution (Kementerian Pengajian Tinggi, 2012), thus Malaysian education system metamorphosis is seen as necessary and on time.

As the global world is embracing the challenges of the $21^{\text {st }}$ century, Malaysia is elevating its education system to prepare the youngsters to not only be knowledgeable but also to acquire the essential soft skills which are higher order thinking skills (henceforth HOTs). Hence, Malaysian Education Blueprint (PPPM) was introduced in 2013. PPPM acknowledges that 3Rs knowledge (Reading, Writing and Arithmetic) 
alone is no longer adequate. The students have to develop the ability to think on a higher level to remain significant and competitive globally. Thus, it is believed that one of the best places to teach and practice HOTs is in the literature classes

\section{REVIEW OF LITERATURE}

\section{Higher Order Thinking Skills (HOTs)}

Higher order thinking skills (HOTs) is a thinking process that goes beyond memorizing / restating facts that are read. HOTs enable the information obtained to be manipulated, to be used in a new way and to be used to solve a new problem. Bloom's taxonomy categorizes analytical, synthesis and evaluation entity as HOTs (Bloom et. al., 1956). HOTs counterpart is known as LOTs (Lower order thinking skills). LOTs, on the other hand, include knowledge and comprehension. Both HOTs and LOTs are cognitive processes (Rajendran, 2013). Table 1 explains the representation of each category in the Bloom's taxonomy.

Table 1: Representation of Each Category in Bloom Taxonomy

\begin{tabular}{|l|l|}
\hline \multicolumn{1}{|c|}{ Category } & \multicolumn{1}{c|}{ Representation } \\
\hline Knowledge / Remembering & $\begin{array}{l}\text { A skill in remembering and / or retrieving } \\
\text { previously learned topic. }\end{array}$ \\
\hline $\begin{array}{l}\text { Comprehension / } \\
\text { Understanding }\end{array}$ & A skill in processing new information \\
\hline Application / Applying & $\begin{array}{l}\text { A skill in applying learned information / } \\
\text { knowledge to solve a new problem / situation. }\end{array}$ \\
\hline Analysis / Analysing & A skill in recognizing relationships among parts. \\
\hline Synthesis / Evaluating & A skill in producing a new product. \\
\hline Evaluation / Creating & A skill in making judgments / solve a problem \\
\hline
\end{tabular}

(Source: Munzenmaier \& Rubin, 2013)

The table below demonstrates examples of accompanying verbs for the different levels of Bloom taxonomy.

Table 2: Bloom Taxonomy Categories and the Accompanying Verbs

\begin{tabular}{|l|l|}
\hline \multicolumn{1}{|c|}{ Level } & \multicolumn{1}{c|}{ Accompanying verbs } \\
\hline Knowledge & $\begin{array}{l}\text { identify, describe, name, label, } \\
\text { recognize, reproduce, follow }\end{array}$ \\
\hline Comprehension & $\begin{array}{l}\text { summarize, convert, defend, } \\
\text { paraphrase, interpret, give examples }\end{array}$ \\
\hline Application & $\begin{array}{l}\text { build, make, construct, model, } \\
\text { predict, prepare }\end{array}$ \\
\hline Analysis & $\begin{array}{l}\text { compare/contrast, break down, } \\
\text { distinguish, select, separate }\end{array}$ \\
\hline
\end{tabular}




\begin{tabular}{|l|l|}
\hline Synthesis & categorize, generalize, reconstruct \\
\hline Evaluation & $\begin{array}{l}\text { appraise, critique, judge, justify, } \\
\text { argue, support }\end{array}$ \\
\hline
\end{tabular}

(Source: Munzenmaier \& Rubin, 2013)

The table below contains examples of HOTs questions that could entice HOTs answers from the students. Below are examples of questions:

Table 3: Examples of HOTs Questions

\begin{tabular}{|c|c|}
\hline Level & Examples of questions \\
\hline Analysis & $\begin{array}{l}\text { - Which events could not have happened? } \\
\text { - If ... happened, what might the ending have been? } \\
\text { - How is ... similar to...? } \\
\text { - What do you see as other possible outcomes? } \\
\text { - Why did ... Changes occur? } \\
\text { - Can you explain what must have happened when...? } \\
\text { - What are some of the problems of...? } \\
\text { - Can you explain what must have happened when ...?? }\end{array}$ \\
\hline Synthesis & $\begin{array}{l}\text { - Is there a better solution to ...? } \\
\text { - Judge the value of ... What do you think about ...? } \\
\text { - Can you defend your position about ...? } \\
\text { - Do you think ... is a good or bad thing? } \\
\text { - How would you have handled ...? } \\
\text { - What changes to ... would you recommend? } \\
\text { - Do you believe ...? How would you feel if...? } \\
\text { - How effective are ...? } \\
\text { - What are the consequences ...? } \\
\text { - What influence will ... have on our lives? }\end{array}$ \\
\hline Evaluation & $\begin{array}{l}\text { - } \quad \text { Can you design a ... to ...? } \\
\text { - Can you see a possible solution to ...? } \\
\text { - } \quad \text { If you had access to all resources, how would you deal } \\
\text { with ...? } \\
\text { - Why don't you devise your own way to ...? } \\
\text { - What would happen if ...? } \\
\text { - How many ways can you ...? } \\
\text { - Can you create new and unusual uses for ...? } \\
\text { - Can you develop a proposal which would ...? }\end{array}$ \\
\hline
\end{tabular}

(Source: Pohl, 2000)

Be it critical thinking, thinking skills, creative thinking, deductive thinking, rational thinking, analogical thinking or HOTs, they are a variation of mental processes that require discipline and practice. However, it is essential to realise and acknowledge that these skills are not mutually exclusive. Often time, there is a connection or overlap between one skill to another (Rajendran, 2013). Rajendran further explains that HOTs and LOTs are two big umbrellas housing two major mental processes known to us as 
critical and creative thinking. The critical and creative thinking, on the other hand, impregnate all other types of thinking skills such as the formerly mentioned.

\section{Challenges in Teaching Higher Order Thinking Skills}

One of the primary challenges of teaching HOTs is the inadequate exposure and knowledge of what HOTs is among teachers. Therefore, retraining is seen as vital. Teachers should be sent for courses, seminars or in-house trainings on regular intervals to equip them with current changes and methods and ideas in teaching. Unfortunately, the courses that these teachers attended are seen to emphasise on theories (Rosnani Hashim, 2010) instead of on ideas or teaching strategies that incorporate HOTs which they can emulate and get inspired from.

According to Muhammad Kamarul Kabilan (2013), there are two possible factors why the teachers are ambivalent in teaching thinking skills. First, the teachers do not have time to plan and re-plan a lesson plan incorporating thinking skills as not only are they overwhelmed with their teaching responsibilities but there are also other commitment such as clerical tasks that are time-consuming and energy draining. This forces the teachers to multi-task. Eventually, the teachers are forced to make use of readily available materials which may have been used and recycled countless times. The teachers too are seen to be struggling with the execution of the lesson.

Continuous training will give room for the teachers to improve their skills and knowledge in teaching HOTs effectively and interestingly. According to Habsah Hussin (2002), the teachers are not provided with comprehensive and systematic continuous professional development training scheme to aid them to teach thinking skills. It is hoped that with constant retraining the teachers and student-teachers would not fall back to the conventional teaching method.

In order to aid these teachers, it is beneficial if there is an array of resource materials that they can use at their disposal. This will motivate them to try to incorporate thinking skills into their teaching and not get frustrated when they have no reference or teaching materials to aid them. As the teachers accustom themselves in incorporating thinking skills in their teaching, their ideas will nourish. They will be opened to suggestions and grow creative in their teaching. This will eventually benefit the students. Currently, resource materials such as teacher guides, resource books, posters, CDs, DVDs, or internet-based materials are scarce. According to Synder and Synder (2008), even though there is chapters in the textbooks that focus on critical thinking discussion questions, these are not adequate to help teachers.

It is imperative to provide the teachers with relevant teaching materials as they view designing and grading assignments (Synder \& Synder, 2008) using thinking skills arduous compared to marking objective questions or true-false statements. Forming subjective questions to challenge the students' thoughts and enable them to apply their knowledge and opinion into the assigned tasks is challenging as well as demanding. In addition, Beachboard and Beachboard's findings showed that students too are not keen on writing task and unstructured problem-solving (2010). 
Aside from that, the teachers' confidence and preparedness (Rajendran, 2013) are also an issue. In teaching HOTs, teachers have to infuse the thinking skills with the content knowledge without sacrificing the syllabus and at the same time making sure that the students will be able to perform in their examinations. This leaves the teachers in a dilemma of either teaching for HOTs or teaching for exams. Baildon and Sim (2009) quoted a Singaporean teacher who shared the dilemma of teachers who are pressured by their stakeholders to teach for examinations. Consequently, teaching becomes very much exam-oriented. This is a similar issue that is silently plaguing the Malaysia education system.

\section{Why Critical Thinking Module is Significant?}

Embracing the $21^{\text {st }}$ century, it is realised that the conventional chalk and talk is no longer seen as relevant. In lineor with the introduction of PPPM, many teaching tools and modules at promoting $21^{\text {st }}$ learning have been introduced. For instance, at present the teachers are exposed to MAPPA 21, i-Think, Virtual Learning Environment (VLE) and the like. This is because the end objective of today's education is to mold the students into thinkers. Hence, teachers have to quickly embrace these changes as lessons of the $21^{\text {st }}$ century entail student-centered learning, collaborative learning, skillbased, HOT practical, group-based, community-based, formative assessment and lifelong learning. Even the classroom setting is changing. No longer are students sitting in twos. Instead, they are now sitting in clusters. There are areas to showcase the students' work and students' activities corner. The sitting arrangement is proposed as to enable communication, collaboration as well as critical and creative thinking (4C) to take place (NEA, 2010). These $4 \mathrm{C}$ concepts that are highlighted in the $21^{\text {st }}$-century teaching result in the introduction of various teaching tools such as traffic lights, reward, parking lot, KWHL, gallery walk, shout out, 3 stray 1 stay, Kahoot, flipped classroom - to name a few. This is where Critical Thinking Module (henceforth CTM) plays its part. CTM is a teaching tool that teachers can use, adapt and adopt to suit their students' needs and proficiency in their effort to promote HOTs among the students. The medium suggested is Literature.

\section{PURPOSE OF THE STUDY}

The research objective is to analyse how the CTM as a teaching module enhance the students' ability to analyse, synthesise and evaluate. Therefore, the research question is: How does the CTM enhance the students' ability to analysis, synthesise and evaluate.

\section{METHODOLOGY}

\section{Research Design}

This research employs the method of the descriptive case study. A case study is a suitable design when one is interested to look into educational phenomena (Merriam, 1988) as it allows the case to be studied in its actual state (Yin, 2009). Thus, the data gathered would be very authentic, relevant, significance and true to the case study. 
Hence, this allows the researcher an in-depth and holistic understanding of the situation researched.

\section{Sample}

The subjects for this case study were chosen based on purposive sampling. The researcher chooses 9 Form 4 (aged 16) Malay subjects who are studying in a cluster school in Kinta Utara, a district in the state of Perak, Malaysia. They speak Bahasa Melayu as their first language and have moderate to good English proficiency. The students come from various social economic backgrounds. The subjects are all Science stream students.

\section{Research Instruments}

The main instrument of the research is the CTM. It consists of a short story, lesson plans, in-class teaching ideas and follow up activities. The short story that is used is Mariah by Che Husna Azhari. There are 5 lesson plans aiming to teach plot, setting, characters, themes and moral values. The second research instrument is the test questions. There are 3 tests that the students have to sit for. The subjects are allocated 1 hour and 30 minutes to finish the tests. Each test comprises of 3 main questions. Some of the questions have sub-questions. The subjects were advised to spend 30 minutes on each question.

\section{Data Analysis and Procedures}

In collecting the necessary data, the researchers gave the subjects one week to read the short story. On the second week, the class started. Each lesson was taught using the lesson plans and activities proposed. At the end of the last lesson taught, the students sat for the 3 designated tests. The test scripts were collected and marked by external raters using the Holistic Scoring Rubrics. The subjects' tests papers were appointed with Band $1-4$. The raters focused on analysing each answer for analysis, synthesis and evaluation thoughts.

\section{FINDINGS AND DISCUSSION}

\section{Analysis skill}

Test script 1: Assuming Mariah turns down Tuk Imam's proposal, what do you think the villagers, men and women, will think of her? Why?

Table 4: Subject 1 - Low Intermediate Proficiency

\begin{tabular}{|l|l|}
\hline L1 & $\begin{array}{l}\text { I think the villagers will feel happy because the men can try to tackle } \\
\text { Mariah and proposed her to be a wife. }\end{array}$ \\
\hline L2 & The women in the village might feel very frustrated and terrified. \\
\hline L3 & $\begin{array}{l}\text { This is because they might think that Mariah wants to seduce their } \\
\text { husband. }\end{array}$ \\
\hline
\end{tabular}


L4 Also, the women terrified that her husband will more frequently go to Mariah's stall.

Inferring from the way the womenfolk treated Mariah and how the men enjoyed her sight, Subject 1 anticipated that the villagers would be happy (L1) if Mariah turned down Tuk Imam's proposal. The subject was able to put herself in the shoes of the women and could understand how the womenfolk see Mariah as a threat, therefore, the frustration and fright (L2) that they experienced. Subject 1 justified her opinion by indicating that the women might assume Mariah had an ulterior motive which was to go after the men in the village (L3) and they were concerned should their husbands pay frequent visits to Mariah's stall (L4).

\section{Table 5: Subject 2 - Intermediate Proficiency}

\begin{tabular}{|l|l|}
\hline L1 & $\begin{array}{l}\text { The villagers, both men and women, will think that Mariah is kind-hearted } \\
\text { but also stupid because firstly she will not make the relationship between } \\
\text { Tuk Imam and Cik Yam become cold and far. }\end{array}$ \\
\hline L2 & $\begin{array}{l}\text { They think Mariah is stupid because she did not grab the chance to make } \\
\text { her life easier. }\end{array}$ \\
\hline L3 & $\begin{array}{l}\text { If she were to marry Tuk Imam there will be somebody to take care of her } \\
\text { and give protection to her. }\end{array}$ \\
\hline
\end{tabular}

Table 5 shows that Subject 2 was able to gauge how the villagers would think kindly of Mariah but there would also be negative criticism to her decision (L1). Subject 2 seemed to understand the society well that she was able to foresee how the society was going to react and think of Mariah. Subject 2 also showed that she understood the kind of life Mariah was facing in the story based on her justification that being married was one of the ways to have a better life (L2). She further explained the phrase 'to make her life easier' by specifying it to caring and protecting Mariah (L3). Subject 2 was able to place herself in the shoes of a woman who needed care and protection especially in the era when the story was written.

\section{Table 6: Subject 3 - High Intermediate Proficiency}

\begin{tabular}{|l|l|}
\hline L1 & They will handle this issue by making assumptions and spread gossips. \\
\hline L2 & $\begin{array}{l}\text { The men would think that Mariah is hard to get and that they will have } \\
\text { chance to marry her. }\end{array}$ \\
\hline L3 & The women would gossip about Mariah and Cik Yam. \\
\hline L4 & $\begin{array}{l}\text { They will also feel scared if there are any chances that Mariah is in an } \\
\text { affair with their husband. }\end{array}$ \\
\hline
\end{tabular}

The above test script shows how Subject 3 was able to break down the bits and pieces of information from the short story and concluded that the society would make assumptions and gossip about Mariah if she turned down Tuk Imam's proposal. Subject 3 also speculated that the men would think Mariah was playing hard to get (L2) while the women would talk behind both Cik Yam and Mariah (L3). This conclusion might have been derived based on what Subject 3 had seen or heard either in everyday life or from TV dramas that she watched. 
In conclusion, all 3 subjects showed that they were practicing analysing skill whereby they managed to examine and break down the information from the short story to understand the cause and effect questions. They made their stance stronger with justification and evidences from the text. Among the techniques used to analyse the given questions were inferencing, providing justification, speculating and anticipating. Instead of making sweeping statements their thoughts and opinions were justified and explained. Hence, the excerpts above prove that the subjects did practice analysis skill in their thinking.

\section{Synthesis skill}

Test script 2: Suppose you could change the title of the story, how would you change it and why?

\section{Table 7: Subject 1 - Low Intermediate Proficiency}

\begin{tabular}{|l|l|}
\hline L1 & $\begin{array}{l}\text { I would change the title of the story to the "why would innocent woman } \\
\text { always have a bad life?" }\end{array}$ \\
\hline L2 & $\begin{array}{l}\text { I choose that title because I want to show that Cik Yam is innocent and } \\
\text { devoted wife need to sacrifice her love. }\end{array}$ \\
\hline L3 & $\begin{array}{l}\text { It is unfair to Cik Yam that takes care of her husband with full of love } \\
\text { need to share her husband with someone else. }\end{array}$ \\
\hline L4 & $\begin{array}{l}\text { Cik Yam's life is so sad because she didn't express her sadness to her } \\
\text { husband. }\end{array}$ \\
\hline L5 & She just accepts the fate and keeps the feeling by herself. \\
\hline L6 & $\begin{array}{l}\text { But at the end of the story, she will get the reward in hereafter because } \\
\text { she has sacrificed a lot to make someone else happy. }\end{array}$ \\
\hline L7 & It shows that everything happens for a reason. \\
\hline
\end{tabular}

Subject 1 managed to create a new title for Mariah (L1) and she was able to characterize Cik Yam as an innocent and devoted wife (L2). Her analysis of the detail of the story was evidence when she could sense Cik Yam's emotional turmoil in dealing with Tuk Imam's decision to remarry. She felt Cik Yam's pain and knew the unfairness Cik Yam was experiencing and how Cik Yam was suffering in keeping it to herself. Thus she concluded Cik Yam's life as sad (L4). Being a woman who was weak and did not have much say in her husband's decision to remarry, she succumbed to fate (L5). Subject 1, however, kept a positive tone when she related Cik Yam's sacrifice to the reward (L6) that was promised to women who sustained God's test like Cik Yam's and concluded that everything happened for a reason (L7).

\section{Table 8: Subject 2 - Intermediate Proficiency}

\begin{tabular}{|l|l|}
\hline L1 & I will change the title of the story to It's Called Love. \\
\hline L2 & $\begin{array}{l}\text { The reason is because love can make everyone change their principle and } \\
\text { their mind. }\end{array}$ \\
\hline L3 & $\begin{array}{l}\text { As example, Tuk Imam loved Cik Yam so much but because of love, he } \\
\text { want to marry Mariah till his decision hurt his devoted wife's feeling. }\end{array}$ \\
\hline L4 & $\begin{array}{l}\text { Love also can make everyone to sacrifice everything include their } \\
\text { feeling. }\end{array}$ \\
\hline
\end{tabular}


\begin{tabular}{|l|l}
\hline L5 & Cik Yam will do everything for Tuk Imam as long as he will not marry
\end{tabular} again but because she want to Tuk Imam happy she sacrifice her feeling and give the permission to Tuk Imam for polygamy.

Table 8 shows Subject 2 successfully create a new title for the short story Mariah (L1). She renamed the short story 'It's Called Love' as she realised love is capable of changing people (L2) and influencing them into doing things that they would not usually do (L3). She compared this to Cik Yam's love that drove her to sacrifice (L5) her own happiness over Tuk Imam's.

Table 9: Subject 3 - High Intermediate Proficiency

\begin{tabular}{|l|l|}
\hline L1 & I would change the title to 'I know I'm not the only one'. \\
\hline L2 & This is because it reflects both Che Yam's and Mariah's feelings. \\
\hline L3 & Both of them have to share their husband's love towards them. \\
\hline L4 & $\begin{array}{l}\text { Both of them stay loyal to their husband even though he has to divide it } \\
\text { to half and they know the fact they have to share the love too. }\end{array}$ \\
\hline
\end{tabular}

Subject 3 created a title focusing on the feelings of the main female characters, Cik Yam and Mariah. She was foreseeing the characters' life after Tuk Imam's marriage to Mariah. Though the title sounded sad (L1) but the main female characters persisted and embraced polygamy with a clear conscience (L3-4).

In conclusion, all of the subjects were able to practice synthesizing skill whereby they are able to create a new title for Mariah. They justified the title they recreated using either details from the text or even their schemata of their society and knowledge of their religion. This shows that HOTs did take place.

\section{Evaluation skill}

Test script 3: In your opinion, was Tuk Imam's argument to take another wife convincing? Explain your answer in details.

Table 10: Subject 1 - Low Intermediate Proficiency

\begin{tabular}{|l|l|}
\hline L1 & In my opinion, Tuk Imam's argument to take another wife is convincing. \\
\hline L2 & This is because children are the symbol of love. \\
\hline L3 & People might talk bad about Tuk Imam and Cik Yam. \\
\hline L4 & Children also make a family become happier. \\
\hline L5 & $\begin{array}{l}\text { The children could shine the family with laughter and memorable } \\
\text { moments. }\end{array}$ \\
\hline L6 & $\begin{array}{l}\text { This is because if they didn't have any children, the family bond } \\
\text { becomes dull and not as happy as there are children in the house. }\end{array}$ \\
\hline L7 & $\begin{array}{l}\text { Next, children will take after any duty or work from their father and } \\
\text { mother. }\end{array}$ \\
\hline L8 & $\begin{array}{l}\text { That's why if parents did not have anyone to take after their duty, it's like } \\
\text { their life is not use and anybody will remember them after they have gone. }\end{array}$ \\
\hline
\end{tabular}


Table 10 shows Subject 2 agreed to Tuk Imam's idea to take a second wife. Her opinion was supported with a few reasons. She associated a happy family with having children and laughter (L4 \& 5). This was the perception of the society in general and Subject 2 was applying the perception here. She compared this to a childless family and used the adjective 'dull' and the phrase 'not as happy' (L6). She concluded her argument with the importance of having a child to take over the duty of their parents as well as to remember the parents after their demise (L8).

\section{Table 11: Subject 2 - Intermediate Proficiency}

\begin{tabular}{|l|l|}
\hline L1 & $\begin{array}{l}\text { In my opinion, Tuk Imam's argument to take another wife is not } \\
\text { convincing because if he marry with Mariah for having children why not } \\
\text { he marry the second wife a long time ago. }\end{array}$ \\
\hline L2 & Why must with Mariah and not other women who is still virgin. \\
\hline L3 & This is totally shown that Tuk Imam marry with Mariah because of lust. \\
\hline L4 & $\begin{array}{l}\text { Mariah's face look alike his first love and this remind him to the sweetest } \\
\text { time with his first love. }\end{array}$ \\
\hline L5 & That is why he want to marry Mariah. \\
\hline L6 & $\begin{array}{l}\text { I think he knows that he can take other alternatives for having a child with } \\
\text { Cik Yam but because of his lust he still want to marry Mariah the sexy and } \\
\text { hot widow. }\end{array}$ \\
\hline
\end{tabular}

In table 11, Subject 2, managed to share her opinion, she defended her thought, critique and concluded her argument. Subject 2, disagreed with Tuk Imam decision to marry another one with an argument that he should and could have done that a long time ago (L1) instead of waiting until now (that he is rather elderly) to remarry for children. This was the excuse given by Tuk Imam to Cik Yam to marry Mariah. Her second argument questioned why Mariah and not any women who were still young (L2). This could probably be due to the fact that in the short story Mariah was described as a woman in her 40s. Thus she concluded Tuk Imam made his decision to marry Mariah because Mariah reminded him of his first love whom he lost (L4).

\section{Table 12: Subject 3 - High Intermediate Proficiency}

\begin{tabular}{|l|l|}
\hline L1 & $\begin{array}{l}\text { Tuk Imam's argument is convincing because he really wants a child of his } \\
\text { own. }\end{array}$ \\
\hline L2 & $\begin{array}{l}\text { As a pious man, he wanted a child in a halal way rather than to have an } \\
\text { illegitimate child because he is desperate to have one. }\end{array}$ \\
\hline L3 & Taking an orphan as his child wouldn't be the same as having his own. \\
\hline L4 & $\begin{array}{l}\text { Blood is thicker than water but the blood itself must be pure to make sure that } \\
\text { it will always stay thicker than water. }\end{array}$ \\
\hline L5 & $\begin{array}{l}\text { By having a child of his own, Tuk Imam can inherit his knowledge and health } \\
\text { to his own flesh thus making this argument relevant. }\end{array}$ \\
\hline L6 & $\begin{array}{l}\text { Marrying Mariah also has prevent him to be a sinner because he thinks of } \\
\text { another woman everytime. }\end{array}$ \\
\hline L7 & $\begin{array}{l}\text { As a Tuk Imam, he mustn't have such feelings because it is a bad attitude and } \\
\text { the villagers will misunderstood him and will not respect him anymore. }\end{array}$ \\
\hline
\end{tabular}


In table 12, Subject 3 agreed with Tuk Imam's decision to take a second wife. She believed Tuk Imam's decision was wise because he wished for a child of his own and getting married will prevent him from committing adultery (L2). In addition, the marriage would prevent him from committing further sins (L6) as in Islam thinking about a woman who was not meant to be for you was wrong. His thoughts could tarnish his reputation as a Tuk Imam (L7). She further supported Tuk Imam's action by indicating that adopting a child is not an option as blood mattered (L3-4). Thus she believed Tuk Imam's argument was convincing.

In conclusion, it can be seen that all of the students managed to answer the evaluation question well. Their arguments were just, well argued, supported and defended. The subjects' ability to defend, argue and counter argue, critique, conclude and explain was the tool in thinking on the higher level.

\section{CONCLUSION}

The findings presented showed the potential of CTM in promoting and gearing the students towards thinking on a higher level. The subjects' answers to the tests questions showed evidences of HOTs. In their attempt to answer the assigned questions, they illustrated the ability to examine, analyse, compare and contrast, criticize, justified, convince, conclude and evaluate necessary information in sharing their thoughts and ideas. This shows that they were practicing HOTs as proposed by van den Berg (2004) - the verbs that are used in the questions typically will determine the students' level of thinking. The major factor that enables the subjects to demonstrate HOTs in their answers could be related to the text chosen for the case study. A literary text should be able to trigger the students' schemata, should relate to their life experience, activate their prior knowledge and convey a message. Hence it would provide avenues for spontaneous students' responses and involvement. Unsuitable text selection, on the other hand, could turn the students off (Muhamad Kamarul Kabilan, 2013). He adds that comprehending unfamiliar cultures and communities is not only challenging but could also demotivate the students. Wolf, Ballentine and Hill (2000) in an experiment with elementary school students found that authentic Literature which addressed reallife issues enhanced students' engagement with the text. They found that the students were deeply engaged in interacting with each other and were able to respond well to the themes highlighted. Though exposing the students to various literary texts is pivotal but it should not be done at the expanse of the students' comprehension. Thus, this shows how vital it is to be very selective of the literary texts chosen.

With the present urging need for the mastery of HOTs, teachers need all the help they can get in terms of ideas and resources. These will assist them to exhibit creativity and fun in class to produce an engaging lesson where students' affective filter is kept low enough for them to be confident and comfortable to participate in the in-class that could eventually lead to HOTs. This is what CTM is offering - engaging activities and ability to promote HOTs among students. 


\section{REFERENCES}

Baildon, M. C., \& Sim, J. B. Y. (2009). Notions of criticality: Singaporean teachers' perspectives of critical thinking in social studies. Cambridge Journal of Education, 39(4), 407-422. doi: 10.1080/03057640903352481

Beachboard, M. R., \& Beachboard, J. C. (2010). Critical thinking pedagogy and student perceptions of university contributions to their academic development. Informing Science: The International Journal of an Emerging Transdisicpline, 13, 53-71.

Bloom, B. S., Englehard, M. D., Furst, E. J., Hill, W. H., \& Krathwohl, D. R. (1956). Taxonomy of educational objectives: The classification of educational goals: Handbook I cognitive domain. New York, 16, 207. doi: 10.1300/J104v03n01_03

Habsah Hussin. (2002). Suggestions for the implementation of critical thinking skills in teacher education. In Abdul Majid et al., (Eds.), Pemikiran dalam Pendidikan (pp. 67-80). Kota Kinabalu: Universiti Malaysia Sabah.

Kementerian Pengajian Tinggi. (2012). The National Graduate Employability Blueprint 20122017. Putrajaya: Ministry of Higher Education Malaysia.

Merriam, S. (1988). Case study research in education: A qualitative approach. San Francisco: Jossey-Bass.

Muhamad Kamarul Kabilan. (2013). Pedagogies for creative and critical thinking in ELT: An introduction. In Muhamad Kamarul Kabilan, (Ed.), Pedagogies for creative and critical thinking in ELT (pp. 1-5). Selangor: August Publishing.

Munzenmaier, C., \& Rubin, N. (2013). Bloom's taxonomy: What's old is new again. Perspectives, $1-47$. Retrieved from http://www.elearningguild.com/research/archives/index.cfm?id=164\&action=viewonly\& utm_campaign=research-blm13\&utm_medium=email\&utm_source=elg-insider

National Education Association (NEA). (2010). Preparing $21^{\text {st }}$ century students for a global society: An educator's guide to the 'four Cs'. Retrieved from http://www.nea.org/assets/docs/A-Guide-to-Four-Cs.pdf

Pohl, M. (2000). Learning to think, thinking to learn: Models and strategies to develop a classroom culture of thinking. Cheltenham: Hawker Brownlow.

Rajendran, N. S. (2013). Teaching and acquiring higher-order thinking skills: Theory \& practice. Perak: Universiti Pendidikan Sultan Idris.

Rosnani Hashim. (2010). Investigation on the teaching of critical and creative thinking in Malaysia. Jurnal Pendidikan Islam, 10(1), 39-56.

Synder, L. G., \& Synder, M. J. (2008).Teaching critical thinking and problem solving skills. The Delta Phi Epsilon Journal, 50(2), 90-99.

Wolf, S. A., Ballentine, D., \& Hill, L. (2000). Only connect! Cross cultural connections in the reading lives of preservice teachers and children. Journal of Literacy Research, 32(4), 533569.

van den Berg, G. (2004) The use of assessment in the development of higher order thinking skills. Africa Education Review, 1(2), 279-294. doi: 10.1080/18146620408566285

Yin, R. K. (2009). Case study research: Design and methods (4 $\left.{ }^{\text {th }} e d.\right)$. Thousand Oaks, CA: Sage. 